\title{
Às Margens do Aqueronte: Finitude, Autonomia, Proteção e Compaixão no Debate Bioético sobre a Eutanásia
}

\author{
On the Acheron River Banks: Finitude, \\ Autonomy, Protection and Compassion in \\ Bioethic Debate on Euthanasia
}

Rodrigo Siqueira-Batista

\begin{abstract}
RESUMO DE TESE
A eutanásia, ou boa morte, é um dos assuntos centrais na bioética contemporânea, possuindo grande relevância no campo da saúde pública, em um contexto de (1) envelhecimento populacional, (2) ampliação das possibilidades terapêuticas na medicina e (3) finitude de recursos para demandas de saúde cada vez maiores - este último ponto em decorrência, principalmente, de uma composição entre (1) e (2). A despeito das grandes discussões hodiemas sobre a eutanásia, o tema permanece ainda como tabu em muitas sociedades - como no caso do Brasil -, necessitando, deste modo, um tratamento conceitual mais adequado, em relação tanto à conceituação - precisão semântica -, quanto à argumentação.

Neste trabalho, pretendeu-se investigar de forma organizada, os principais aspectos envolvidos no debate moral sobre a boa morte, a partir de uma reflexão teórica sobre a literatura filosófica e bioética pertinente. O resultado da pesquisa foi organizado em cinco artigos, articulados entre si. Com efeito, partindo-se de um breve comentário acerca dos antecedentes históricos relativos à eutanásia, procurou-se delimitar seu conceito - confrontando-o com outras definições atinentes à bioética do fim da vida, como o suicídio assistido, a distanásia, a ortotanásia e a mistanásia, apresentar os principais argumentos pró e contra a sua realização e discutir o emprego do conceito de morte em seu debate moral. Ademais, questões como o se-saber-mortal, o padecimento, a autonomia e a compaixão foram também contempladas, utilizando-se, para tal, os referenciais teóricos da bioética da proteção. Propõe-se, ao final, que a eutanásia seja moralmente defensável nas circunstâncias em que se está diante de um sujeito em plena vivencia de sua (1) finitude, em um contexto de (2) profundo sofrimento, o qual, estribado em sua (3) autonomia, decide morrer, necessitando, nestes termos, da proteção de um outro - capaz de garantir sua autodeterminação , o qual, ao the conduzir à boa morte, realiza um genuíno ato de (4) compaixão.
\end{abstract}

Orientador: Prof. Dr. Fermin Roland Schramm

Defesa de Tese de Doutorado em Ciências pelo Programa de Pós-graduação em Saúde Pública, Escola Nacional de Saúde Pública Sérgio Arouca, Fundação Oswaldo Cruz (ENSPFIOCRUZ), em 16 de fevereiro de 2006.

Disponível nas bibliotecas: Escola Nacional de Saúde Pública Sérgio Arouca da Fundação Oswaldo Cruz, Fundação Educacional Serra dos Órgãos e Pontifícia Universidade Católica do Rio de Janeiro.

\section{Endereço para correspondência:}

Prof. Dr. Rodrigo Siqueira Batista Avenida Alberto Torres, 111. Alto - Teresópolis - RJ CEP.: 25964-000 - E-mail: anaximandro@hotmail.com 